\title{
Dental environment and war-related stress among dental students, Yemen
}

Esam Halboub, ${ }^{1,2}$ Mohammad Nasser Alhajj, ${ }^{3}$ Mohammed Ali Al-Wesabi, ${ }^{4}$ Saba Al-Sanaani ${ }^{5}$ and Abdulbaset Mufadhal ${ }^{6}$

${ }^{1}$ Department of Maxillofacial Surgery and Diagnostic Sciences, College of Dentistry, Jazan University, Saudi Arabia. ${ }^{2}$ Department of Oral Medicine, Oral Pathology and Oral Radiology, Faculty of Dentistry, Sana'a University, Sana'a, Yemen. ${ }^{3}$ Department of Prosthodontics, Faculty of Dentistry, Thamar University, Dhamar, Yemen. ${ }^{4}$ Department of Oral Medicine and Periodontology, Faculty of Dentistry, University of Science and Technology, Sana'a, Yemen. ${ }^{5}$ Faculty of Dentistry, University of Science and Technology, Sana'a, Yemen. ${ }^{6}$ Department of Conservative Dentistry and Endodontics, Faculty of Dentistry, Sana’a University, Sana'a, Yemen. (Correspondence to: Mohammed Nasser Alhajj: m.n.alhajj@hotmail.com).

\begin{abstract}
Background: Education related to health sciences appears to be the most stressful.

Aims: The aim of this study was to evaluate the perceived stress among Yemeni dental students and to explore the effect of the war circumstances on the perceived stress.

Methods: This cross-sectional study targeted all dental students at the two main dental faculties in Yemen. Dental environmental stress questionnaire was used. An extra 12 items (as one domain) were developed to reflect the stress resulting from the current war circumstances.

Results: A total of 1051 dental students participated in this study. The overall dental environmental stress was $1.63 \pm 0.45$. The most significant stressor domain was "workload", followed by "war-related" along with "performance pressure". In general, females, married, and clinical students, and those with lower GPA scored significantly higher stress levels than their counterparts. Regression analysis revealed that the university, sex, and study level as the most significant determinants for most domains.

Conclusions: The level of stress among Yemeni dental students can be considered as moderate to high. This stress was further exacerbated by the war circumstances present.

Keywords: Stress; war-related stress; DES; dental students; Yemen

Citation: Halboub E; Alhajj MN; Al-Wesabi MA; Al-Sanaani S; Mufadhal A. Dental environment and war-related stress among dental students, Yemen. East Mediterr Health J. 2019;25(8):529-536. https://doi.org/10.26719/emhj.19.002

Received: 17/10/17; accepted: 25/09/18

Copyright ( ) World Health Organization (WHO) 2019. Some rights reserved. This work is available under the CC BY-NC-SA 3.0 IGO license (https:// creativecommons.org/licenses/by-nc-sa/3.o/igo).
\end{abstract}

\section{Introduction}

Stress is defined as the body's reaction to a change that entails a physical, mental or emotional response. Such a response may be positive, stimulating and motivating for individuals to do their best, or negative, depressing and reducing an individual's performance $(1,2)$. Perception of stress is not the same among different people; it can be affected by beliefs, attitudes and occupation. In general, education - specifically higher education - poses a substantial amount of stress for enrolled students (3-5). Education related to the health sciences seems to be the most stressful. In this context, dental schools are considered highly stressful learning environments, and stress among dental students has been revealed to be higher than among the general student population (6-8). Dental students' performance can be greatly affected when commencing clinical training, since they become exposed to the same patient-related stressors faced by dental practitioners $(9-12)$.

Dental environment-induced stress can negatively affect students' well-being unless dealt with appropriately. Ultimately, the academic performance of these students will deteriorate $(8,13)$. Stress can be very much expected among dental students not only because of their academic environment, but also because of their social and cultural background, which can provoke or modify stress among such students (14). With no doubt, war and political conflicts have direct and indirect negative consequences on society, including university students (15). In February 2011 the so-called "Arab Spring" extended to Yemen, resulting in political instability and eventually ended up with a war that is still ongoing. The effects of war on dental students have not been widely studied. Apart from one recent study that investigated stress among Libyan dental students during the conflict (16), further studies have not been investigated. The result of this study regarding the stress perception was comparable to conducted studies in other countries. In addition to the Dental Environment Stress (DES) questionnaire, we included an extra domain (12 items) related to the ongoing war In comparison with the Libyan study.

Hence, determining the stress-provoking factors is very important; it will give policy-makers, academic staff and administrators a comprehensive knowledge to modify teaching curricula and/or environment in such a way to be more conducive to students' learning. The aims of this study, therefore, were to evaluate the perceived dental environment-induced stress and sources of such stress among undergraduate dental students in Yemen, 
and to explore whether the current war circumstances add to perceived stress.

\section{Methods}

This descriptive questionnaire-based, cross-sectional study was conducted during the 2106/2017 academic year. It targeted all dental students at two main dental faculties in Sana'a, Yemen: one public, Sana'a University, and one private, University of Science and Technology (UST). Ethical approvals were obtained from the Research Committees at both faculties. The questionnaire was accompanied by a covering letter describing the study and its aims, stressing the confidentiality of the data and the voluntary participation, and asking the participants to sign to confirm his/her inclusion.

For better understanding, a bilingual (Arabic and English) modified version of the DES questionnaire was used. Apart from the demographic data, it comprised 41 items grouped under seven stress-provoking domains as follows: self-efficacy beliefs (nine items), faculty and administration (ten items), workload (six items), patient treatment (four items), clinical training (four items), performance pressure (three items), and social stressors (five items) $(17,18)$. An extra 12 items were developed to reflect what extent students were affected by in the current war circumstances in Yemen; it was referred to as the "War-related stress" domain. However, these domains were not displayed to the students in the distributed questionnaires. Responses to each item in the questionnaire were modified into a three-point Likert scale with $1=$ no stress, $2=$ moderate stress, and $3=$ severe stress. A fourth possible response ( $0=$ not applicable) was added where the stress situation under question is not applicable to the participant.

Completed questionnaires were input into SPSS software version 21 (IBM Corp., Armonk, NY, USA). The study data were presented as frequencies with proportions or means with standard deviations (SDs), as appropriate. The summary scores of the individual domains and of the overall DES, presented as means and SDs, were considered as the dependent variables. Sex, marital status, Grade Point Average (GPA) and level of study were considered as independent variables. Differences in stress by the independent variables were analysed using non-parametric tests (Mann-Whitney U test and Kruskal-Wallis test). Multiple linear regression analyses were then conducted to determine the independent determinants. A P-value less than 0.05 was considered significant.

\section{Results}

A total number of 1507 dental students from both faculties were invited (Sana'a $=875$ with $74 \%$ females and UST $=632$ with $60 \%$ females). Finally, 1052 students participated, representing an overall response rate of $70 \%$. The mean age estimated at $21.11 \pm 1.76$ years (range $=17-29$ years) Almost $72 \%(n=752)$ of the participants were females and $9 \%(n=92)$ were married. The highest proportion of participation was from the first year (approximately $28 \%$, $n=291)$ while the lowest was from fifth year $(15 \%, n=160)$. Most of the students $(74 \%, n=713)$ had a GPA higher than 80\% (Table 1).

For all participants, the overall DES score was $1.63 \pm$ 0.45 out of three. The highest fraction of this stress was attributed to "Workload" $(2.07 \pm 0.54)$ and "War-related

\begin{tabular}{|c|c|c|c|}
\hline & All $(N=1052)$ & Sana'a $(\mathrm{N}=638)$ & UST $(N=414)$ \\
\hline & $\mathbf{N}(\%)$ & $\mathbf{N}(\%)$ & $\mathbf{N}(\%)$ \\
\hline \multicolumn{4}{|l|}{$\operatorname{Sex}(N=1048)$} \\
\hline Male & $296(28.2)$ & $150(23.6)$ & $146(35.4)$ \\
\hline Female & $752(71.8)$ & $485(76.4)$ & $267(64.6)$ \\
\hline \multicolumn{4}{|c|}{ Marital Status $(N=1039)$} \\
\hline Single & 947 (91.1) & $578(92.2)$ & $369(89.6)$ \\
\hline Married & $92(8.9)$ & $49(7.8)$ & $43(10.4)$ \\
\hline \multicolumn{4}{|c|}{ Study level $(\mathrm{N}=1050)$} \\
\hline First & $291(27.7)$ & $199(31.2)$ & $92(22.3)$ \\
\hline Second & $186(17.7)$ & $109(17.1)$ & $77(18.7)$ \\
\hline Third & $224(21.3)$ & $117(18.3)$ & $107(26.0)$ \\
\hline Fourth & $189(18.0)$ & $101(15.8)$ & $88(21.4)$ \\
\hline Fifth & $160(15.2)$ & $112(17.6)$ & $48(11.7)$ \\
\hline \multicolumn{4}{|c|}{ Mark of previous year $(N=967)$} \\
\hline$\leq 70 \%$ & $47(4.9)$ & $30(4.9)$ & $17(4.8)$ \\
\hline$>70 \%-80 \%$ & $207(21.4)$ & $120(19.6)$ & $87(24.5)$ \\
\hline$>80 \%-90 \%$ & $436(45.1)$ & $285(46.6)$ & $151(42.5)$ \\
\hline$>90 \%$ & $277(28.6)$ & $177(28.9)$ & $100(28.2)$ \\
\hline
\end{tabular}


stress" along with "Performance pressure" $(1.84 \pm 0.61$ and $1.83 \pm 0.63$, respectively). For each dental school, Students in Sana'a University scored higher level of stress in all domains except for "patient treatment", "clinical training" and "social stressor", where they scored lower than UST students (Table 2).

Table 3a presents the five highest scored items for all participants and Table $3 \mathrm{~b}$ by university. There were two items related to war situation: "Frequent or permanent power outage due to the current war circumstances" and "Your family's worries about you, due to the current war circumstances, when you go to college", which had scores of $2.25 \pm 0.97$ and $2.24 \pm 0.89$, respectively.

Comparisons of domain scores by different grouping factors are presented in Table 4. Students from Sana'a University had significantly more stress in all domains except for "clinical training", "patient treatment", and "social stressor" where the stress level was lower than that of UST students; however, the latter two were not significant $(P=0.087$ and $P=0.245$, respectively). In addition, although students from Sana'a University had a higher score in performance pressure, the difference was not significant $(P=0.84)$. Females scored significantly higher than males, except for "social stressors" where

\begin{tabular}{lccc}
\hline Table 2 Mean scores of stress among study participants according to DES domains & & & \\
& All & Sana'a & UST \\
mean \pm SD & mean \pm SD & mD \\
Self-efficacy beliefs $(\mathrm{N}=1020)$ & $1.76 \pm 0.56$ & $1.85 \pm 0.54$ & $1.63 \pm 0.57$ \\
Faculty and administration $(\mathrm{N}=962)$ & $1.60 \pm 0.58$ & $1.64 \pm 0.58$ & $1.55 \pm 0.57$ \\
Workload $(\mathrm{N}=1017)$ & $2.07 \pm 0.54$ & $2.12 \pm 0.49$ & $1.99 \pm 0.60$ \\
Patient treatment $(\mathrm{N}=1010)$ & $1.49 \pm 0.97$ & $1.45 \pm 0.98$ & $1.56 \pm 0.95$ \\
Clinical training $(\mathrm{N}=994)$ & $1.23 \pm 0.95$ & $1.16 \pm 0.96$ & $1.32 \pm 0.92$ \\
Performance pressure $(\mathrm{N}=1011)$ & $1.83 \pm 0.63$ & $1.87 \pm 0.59$ & $1.77 \pm 0.69$ \\
Social stressors $(\mathrm{N}=987)$ & $0.97 \pm 0.56$ & $0.95 \pm 0.54$ & $1.00 \pm 0.58$ \\
War-related stress $(\mathrm{N}=1008)$ & $1.84 \pm 0.61$ & $1.94 \pm 0.56$ & $1.70 \pm 0.65$ \\
\hline
\end{tabular}

\section{Table 3a Mean scores of stress related to selected items of DES questionnaire for all participants}

\begin{tabular}{|c|c|c|}
\hline & $\mathbf{N}$ & Mean \pm SD \\
\hline Lack of time to do assigned school work & 1046 & $2.33 \pm 0.80$ \\
\hline Lack of time for relaxation & 1040 & $2.26 \pm 0.86$ \\
\hline Frequent or permanent power outage due to the current war circumstances & 1045 & $2.25 \pm 0.97$ \\
\hline $\begin{array}{l}\text { Your family's worries about you when you go to college due to the current war } \\
\text { circumstances }\end{array}$ & 1045 & $2.24 \pm 0.89$ \\
\hline Overloaded feeling due to huge study syllabus & 1047 & $2.23 \pm 0.83$ \\
\hline
\end{tabular}

\begin{tabular}{|c|c|c|}
\hline \multicolumn{3}{|l|}{ Sana'a } \\
\hline Frequent or permanent power outage due to the current war circumstances & 631 & $2.42 \pm 0.82$ \\
\hline Lack of time to do assigned school work & 632 & $2.40 \pm 0.73$ \\
\hline Overloaded feeling due to huge study syllabus & 633 & $2.35 \pm 0.74$ \\
\hline Fear of failing a course or the year & 634 & $2.33 \pm 0.90$ \\
\hline Competition for grades & 632 & $2.32 \pm 0.78$ \\
\hline \multicolumn{3}{|l|}{ UST } \\
\hline Lack of time to do assigned school work & 414 & $2.22 \pm 0.88$ \\
\hline Lack of time for relaxation & 414 & $2.21 \pm 0.95$ \\
\hline $\begin{array}{l}\text { Your family's worries about you when you go to college due to the current } \\
\text { war circumstances }\end{array}$ & 414 & $2.16 \pm 0.96$ \\
\hline Examinations and quizzes & 414 & $2.06 \pm 0.82$ \\
\hline Fear of being unable to catch up if falling behind & 414 & $2.05 \pm 0.94$ \\
\hline
\end{tabular}




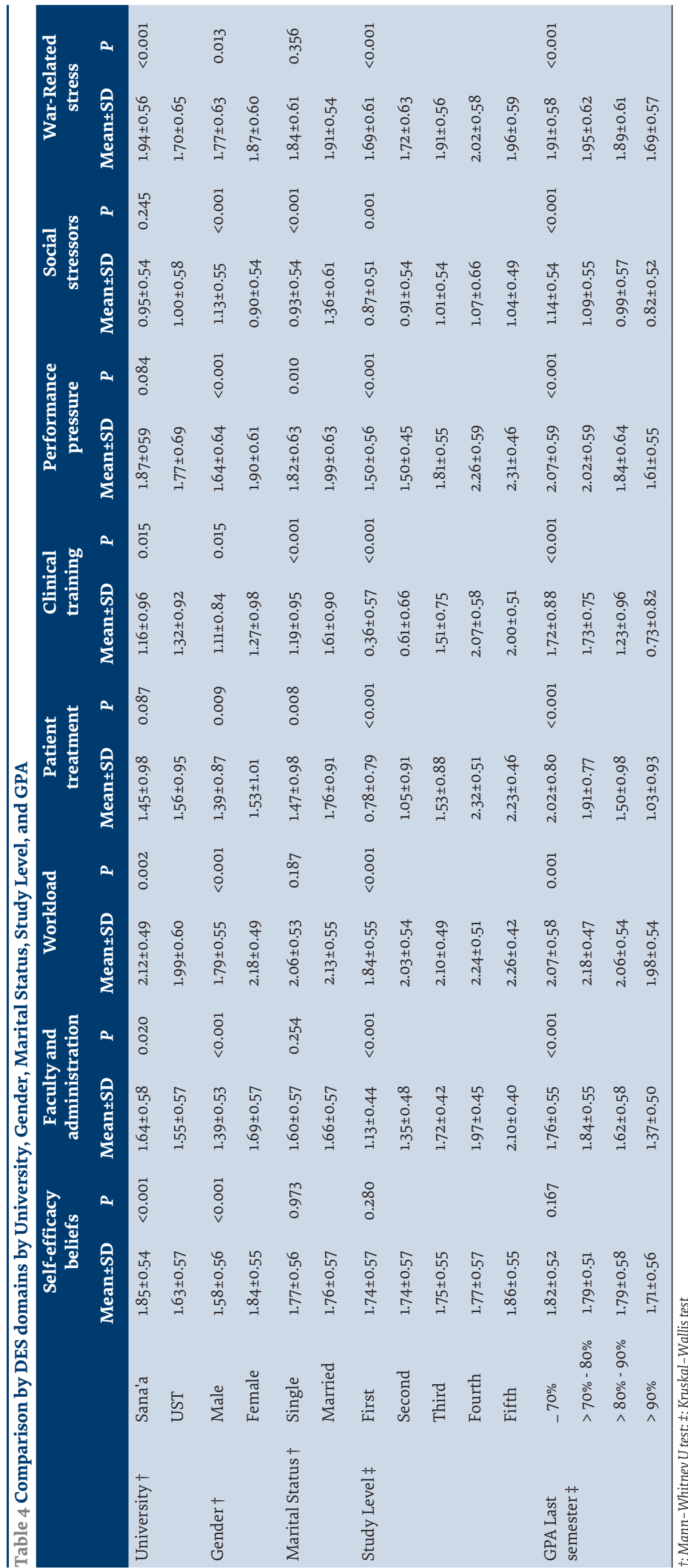

the opposite was indicated. Married students scored higher for stress compared to single students; however, these scores were significantly higher in four of the eight domains ("patient treatment", $P=0.008$; "clinical training", $P<0.001$; "performance pressure", $P=0.015$; and "social stressors", $P<0.001)$. Regarding study levels, it has been shown that stress increased significantly $(P<0.001)$ with progressive study levels except for "Self-efficacy beliefs." Students who had a higher GPA scored significantly $(P<0.001)$ lower levels of stress than their peers, except for "Self-efficacy beliefs."

Multivariate analyses revealed that "clinical training", "faculty and administration", and "patient treatment" were the domains for which the multivariate models explained substantial fractions of their variability: $R^{2}=0.527,0.446$ and 0.386 , respectively. The university, sex and study levels were the most significantindependentdeterminants for most of the domains. Marital status and GPA were less significant determinants (Table 5).

\section{Discussion}

To the best of our knowledge, this study was the first to assess the perceived DES and stress-provoking factors among dental students in Yemen. In addition, it explored whether war circumstances increased such stress. Since March 2015, Yemen has been under an unstable situation due to the war and political conflict. Sana'a city is the capital of Yemen and is one of the most affected governorates countrywide. This study aimed to know to what extent such circumstances may affect dental students' learning performance.

The results of the present study showed that war-related stress ranked the second highest source of perceived stress among dental students in Yemen. The workloadrelated stress ranked the first. This reflects the extent to which these students are determined to handle their study obligations, even under harsh circumstances such as conflict. Nevertheless, these war-related 


\begin{tabular}{|c|c|c|c|c|c|}
\hline \multirow{2}{*}{$\begin{array}{l}\text { Independent variable } \\
\text { Self-efficacy beliefs }\end{array}$} & \multirow[t]{2}{*}{ B } & \multicolumn{2}{|c|}{$95 \% \mathrm{CI}$} & \multirow[t]{2}{*}{ Adjusted $\mathrm{R}^{2}$} & \multirow[t]{2}{*}{ P-value } \\
\hline & & & & & \\
\hline University & -0.217 & -0.289 & -0.145 & 0.080 & $<0.001$ \\
\hline Sex & 0.228 & 0.150 & 0.305 & & $<0.001$ \\
\hline GPA Last semester & -0.056 & -0.097 & -0.014 & & 0.009 \\
\hline \multicolumn{6}{|l|}{ Faculty and administration } \\
\hline Study Level & 0.250 & 0.230 & 0.270 & 0.446 & $<0.001$ \\
\hline Sex & 0.199 & 0.135 & 0.263 & & $<0.001$ \\
\hline University & -0.065 & -0.123 & -0.007 & & 0.029 \\
\hline \multicolumn{6}{|l|}{ Workload } \\
\hline Sex & 0.325 & 0.255 & 0.395 & 0.179 & $<0.001$ \\
\hline Study Level & 0.099 & 0.077 & 0.121 & & $<0.001$ \\
\hline University & -0.109 & -0.173 & -0.044 & & 0.001 \\
\hline \multicolumn{6}{|l|}{ Patient treatment } \\
\hline Study Level & 0.399 & 0.360 & 0.437 & 0.386 & $<0.001$ \\
\hline GPA Last semester & -0.075 & $0-.141$ & -0.008 & & 0.029 \\
\hline \multicolumn{6}{|l|}{ Clinical training } \\
\hline Study Level & 0.471 & 0.441 & 0.501 & 0.527 & $<0.001$ \\
\hline University & 0.127 & 0.039 & 0.214 & & 0.005 \\
\hline Marital Status & 0.184 & 0.033 & 0.335 & & 0.017 \\
\hline \multicolumn{6}{|l|}{ Performance pressure } \\
\hline Study Level & 0.223 & 0.199 & 0.247 & 0.298 & $<0.001$ \\
\hline Sex & 0.174 & 0.097 & 0.251 & & $<0.001$ \\
\hline University & -0.074 & -0.144 & -0.003 & & 0.041 \\
\hline \multicolumn{6}{|l|}{ Social stressors } \\
\hline Marital Status & 0.379 & 0.256 & 0.501 & 0.114 & $<0.001$ \\
\hline Sex & -0.261 & -0.339 & -0.184 & & $<0.001$ \\
\hline GPA Last semester & -0.067 & -0.115 & -0.020 & & 0.006 \\
\hline Study Level & 0.036 & 0.008 & 0.064 & & 0.013 \\
\hline \multicolumn{6}{|l|}{ War-Related Stress } \\
\hline University & -0.262 & -0.339 & -0.184 & 0.084 & $<0.001$ \\
\hline Study Level & 0.072 & 0.042 & 0.102 & & $<0.001$ \\
\hline GPA Last semester & -0.052 & -0.103 & -0.001 & & 0.046 \\
\hline
\end{tabular}

circumstances had obvious effects on these students and causing substantial levels of stress. The results of this study are in the line with existing studies, indicating that dental students are exposed to a heavy workload and academic requirements, which act as sources of stress that affect the psychological and physical health of the students (19-24).

In the present study, the majority of the respondents reported that they had either moderate to severe stress, which was in agreement with other published studies $(25,26)$. 'Workload' was the highest stressor perceived by dental students, and this is consistent with previous studies $(16,19,21,22,27)$. It is known that the dental curriculum is composed of many subjects entailing lectures, laboratory work, and clinical work that consume students' time and energy. Comparing the two universities, the mean score of stress due to workload in Sana'a University was slightly higher than that of UST dental students $(2.12 \pm 0.49$ vs. $1.99 \pm 0.60)$. This might be due to the facilities in the private dental school, which ease the accomplishment of clinical and laboratorial requirements, as well as the fact that the staff-to-student ratio is better in the private dental schools.

Surprisingly, the war-related stress score was lower than that of workload stress. This can be explained by the determination of these students to succeed whatever the prevailing circumstances. However, the workload domain is revealed as an important stressor for students and suggests urgent modifications in the dental curricula are required in order to prioritize quality rather than quantity.

Within the "workload" domain, the most stressful items were "lack of time for relaxation" among all students (mean score $=2.33 \pm 0.80$ ) and among UST dental students (mean score $=2.22 \pm 0.88$ ), and "Frequent 
or permanent power outage due to the current war circumstances" among Sana'a University (mean score $=2.42 \pm 0.82$ ). The timetable of dental students is full of lectures, laboratory work, and clinical sessions, meaning students find little time to relax. Additionally, permanent power outage substantially adds to war-related stress.

Students in clinical years of study (4th and 5 th) scored higher levels of stress in comparison to students in the preclinical years (1st, 2nd and 3rd). This result is similar to that obtained by many previous studies $(20,26,28-31)$. Students at clinical levels of study are increasingly exposed to clinical duties toward their patients, besides theory. Participants with a high GPA (more than 90\%) showed lower levels of stress in all domains. In general, students with a high GPA are well organized, more confident and more productive, and demonstrate the ability to manage their time effectively (32).

This study is one of very few studies that compared the issue of stress among private and public school dental students (17,33). "University" factor along with "study level" and "Marital status" factors were revealed to be significant independent determinants of most of the stress domains. They together explained more than half $(53 \%)$ of the variability in the stress score of "clinical training" domain. Public and private universities have different administration systems, different facilities, different educational environment, and different socioeconomic backgrounds of enrolled students. In accordance with a study among Malaysian dental students, students in public universities had higher levels of stress than their counterparts in private universities (33).

Furthermore, "Marital status" appeared to be an independent factor for stress. Family responsibilities and duties of married dental students, as well as having children, increase psychological pressure and affecting the overall amount of stress. As revealed by other studies, married students are expected to reside in their own homes and live away from parents' home (34-36).

In our study, female students had higher levels of stress than male counterparts in all stress domains except for "social stressors" domain. Many studies reported gender-related differences regarding DES (17,20,37-39). Female students were more open to express stress issues than their male counterparts, and their response to stressors also differed. Some studies suggested that gender differences could be explained by the fact that males are simply less emotionally expressive $(17,40)$.

\section{Conclusion}

DES perceived by dental students in Yemen is generally moderate to high and it is exacerbated by the war circumstances. The study showed the effects of external factors on stress perception among dental students.

Funding: None.

Competing interests: None declared.

\section{L'environnement dentaire et le stress lié à la guerre chez les étudiants yéménites en médecine dentaire \\ Résumé}

Contexte : Les études en sciences de la santé semblent être celles qui génèrent le plus de stress.

Objectifs : La présente étude avait pour objet d'évaluer le stress perçu par les étudiants en médecine dentaire yéménites et d'analyser l'impact des situations de guerre sur ce ressenti.

Méthodes : La présente étude transversale ciblait tous les étudiants en médecine dentaire des deux principales facultés dentaires du Yémen. Un questionnaire sur le stress en environnement dentaire a été utilisé aux fins de cette étude. Plus de 12 items (constituant un seul domaine) ont été définis pour rendre compte du stress dû à la situation de guerre que connaît actuellement ce pays.

Résultats: Un total de 1051 étudiants en médecine dentaire ont participé à cette étude. Globalement, le stress en environnement dentaire était de 1,63 $\pm 0,45$. La charge de travail constituait le facteur de stress le plus important, suivie par le facteur lié à la guerre ainsi que la pression en termes de performance. En général, les femmes mariées et les étudiants en médecine clinique ainsi que ceux dont la moyenne pondérée était plus faible présentaient un niveau de stress significativement plus élevé que leurs camarades. L'analyse de régression a montré que l'université, le sexe et le niveau d'étude constituaient les déterminants les plus importants dans la plupart des domaines.

Conclusions : Le niveau de stress parmi les étudiants en médecine dentaire yéménites est considéré comme étant modéré à élevé. Ce stress était encore aggravé par la situation de guerre que connaît ce pays. 


$$
\begin{aligned}
& \text { بيئة طب الأسنان والإجهاد المتعلق بالحرب بين طلاب طب الأسنان، اليمن }
\end{aligned}
$$

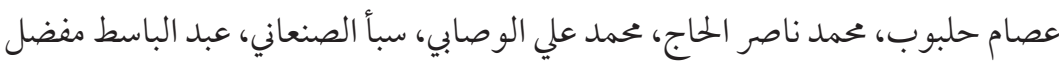

$$
\begin{aligned}
& \text { الخلاصة } \\
& \text { الخلفية: يبدو أن التعليم المرتبط بالعلوم الصحية هو الأكثر إجهادًا. }
\end{aligned}
$$

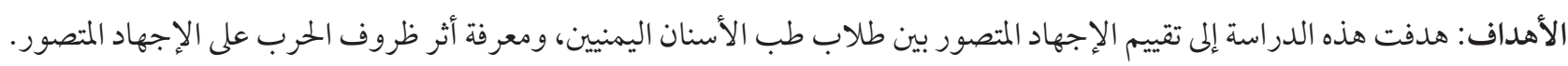

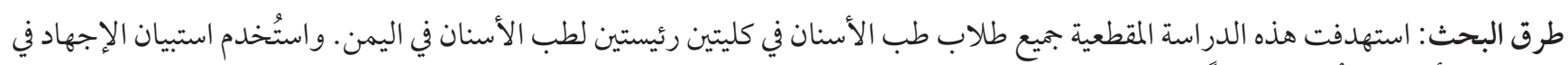

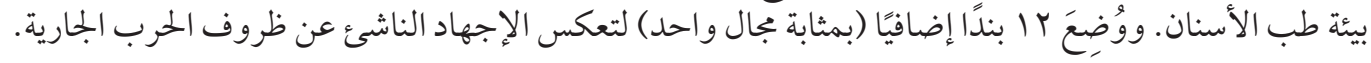

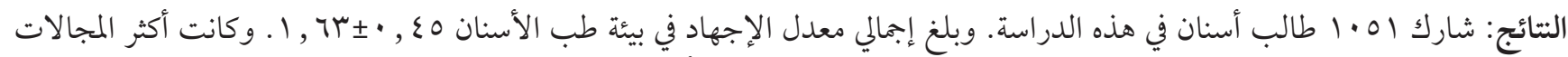

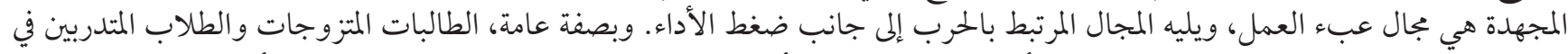

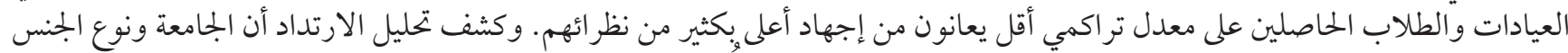

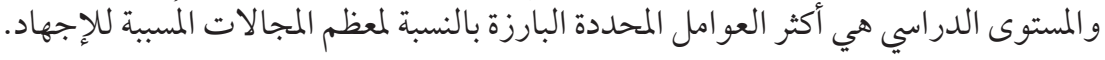

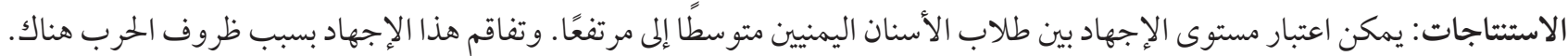

\section{References}

1. Cohen S, Kessler RC, Gordon LU. Strategies for measuring stress in studies of psychiatric and physical disorders. In: Cohen S, Kessler R, Gordon U, editors. Measuring stress: A guide for health and social scientists. NewYork: Oxford University Press; 1995.

2. Folkman S. Stress: Appraisal and Coping. In: Gellman MD, Turner JR, editors. Encyclopedia of Behavioral Medicine. New York (NY): Springer New York; 2013. http://dx.doi.org/10.1007/978-1-4419-1005-9_215

3. Almeida DM, Kessler RC. Everyday stressors and gender differences in daily distress. J Pers Soc Psychol. 1998;75(3):670-80. http://dx.doi.org/10.1037/0022-3514.75-3.670

4. Dyrbye LN, Thomas MR, Shanafelt TD. Systematic review of depression, anxiety, and other indicators of psychological distress among U.S. and Canadian medical students. Acad Med. 2006;81(4):354-73. http://dx.doi.org/10.1097/00001888-200604000-00009

5. Li C, Liu JC, Xiao X, Chen X, Yue S, Yu H, et al. Psychological distress and type 2 diabetes mellitus: a 4-year policemen cohort study in China. BMJ Open. 2017;7(1):e014235. http://dx.doi.org/10.1136/bmjopen-2016-014235

6. Tosevski DL, Milovancevic MP, Gajic SD. Personality and psychopathology of university students. Curr Opin Psychiatry. 2010;23(1):48-52. http://dx.doi.org/10.1097/YCO.obo13e328333d625

7. Lloyd C, Musser LA. Psychiatric symptoms in dental students. J Nerv Ment Dis. 1989;177(2):61-9. http://dx.doi. org/10.1097/00005053-198902000-00001

8. Schmitter M, Liedl M, Beck J, Rammelsberg P. Chronic stress in medical and dental education. Med Teach. 2008;30(1):97-9. http://dx.doi.org/10.1080/01421590701769571

9. Fredericks MA, Mundy P. Dental students: relationship between social class, stress, achievement, and attitudes. J Am Coll Dent. 1967;34:218-28.

10. Davis EL, Tedesco LA, Meier ST. Dental student stress, burnout, and memory. J Dent Educ. 1989;53:193-5.

11. Stewart DW, de Vries J, Singer DL, Degen GG, Wener P. Canadian dental students' perceptions of their learning environment and psychological functioning over time. J Dent Educ. 2006;70:972-81.

12. Cardall WR, Rowan RC, Bay C. Dental education from the students' perspective: curriculum and climate. J Dent Educ. 2008;72:600-9.

13. Uraz A, Tocak YS, Yozgatligil C, Cetiner S, Bal B. Psychological well-being, health, and stress sources in Turkish dental students. J Dent Educ. 2013;77:1345-55.

14. Manstead ASR. The psychology of social class: How socioeconomic status impacts thought, feelings, and behaviour. Br J Soc Psychol. 2018;57(2):267-91. http://dx.doi.org/10.1111/bjso.12251

15. Al-Jbarat M. Yemen Crises; Historical Roots and Solution Spheres. GJHSS. 2017;16:1-8.

16. Arheiam A, El Tantawi M, Al-Omami M, Peeran S, Elmisalati W. Perception of Stress among Dental Students Living in A War-Affected Zone. J Dent Educ. 2019;83:48-55.

17. Alhajj MN, Khader Y, Murad AH, Celebic A, Halboub E, Marquez JR, et al. Perceived sources of stress amongst dental students: A multicountry study. Eur J Dent Educ 2018;22:258-71.

18. Al-Sowygh ZH, Alfadley AA, Al-Saif MI, Al-Wadei SH. Perceived causes of stress among Saudi dental students. King Saud Univ J Dent Sci. 2013;4:7-15. 
19. Rosli TI, Abdul RR, Abdul RS, Ramli R. A survey of perceived stress among undergraduate dental students in Universiti Kebangsaan Malaysia. Singapore Dent J. 2005;27:17-22.

20. Al-Saleh SA, Al-Madi EM, Al-Angari NS, Al-Shehri HA, Shukri MM. Survey of perceived stress-inducing problems among dental students, Saudi Arabia. Saudi Dent J. 2010;22:83-8. http://dx.doi.org/10.1016/j.sdentj.2010.02.007

21. Montero-Marín J, Demarzo MMP, Stapinski L, Gili M, García-Campayo J. Perceived stress latent factors and the burnout subtypes: a structural model in dental students. PLoS One. 2014;9(6):e99765. http://dx.doi.org/10.1371/journal.pone.0099765

22. Al-Sowygh ZH. Academic distress, perceived stress and coping strategies among dental students in Saudi Arabia. Saudi Dent J. 2013;25:97-105. http://dx.doi.org/10.1016/j.sdentj.2013.05.002

23. Jain M, Sharma A, Singh S, Jain V, Miglani S. The stress of clinical dental training: A cross-sectional survey among dental students and dentists of a dental college in India. J Indian Assoc Public Health. 2016;14:434. http://dx.doi.org/10.4103/23195932.195827

24. Murad AH, Alhajj MN. Evaluation of stress among undergraduate dental students in Al-Qadisiyah University-Iraq. J Stoma. 2017;70:171-82.

25. Elani HW, Allison PJ, Kumar RA, Mancini L, Lambrou A, Bedos C. A systematic review of stress in dental students. J Dent Educ. 2014;78:226-42.

26. Bhayat A, Madiba TK. The self-perceived sources of stress among dental students at a South African Dental School and their methods of coping. SADJ. 2017;72:6-10.

27. Elani HW, Bedos C, Allison PJ. Sources of stress in Canadian dental students: a prospective mixed methods study. J Dent Educ. 2013;77:1488-97.

28. Abu-Ghazaleh SB, Rajab LD, Sonbol HN. Psychological stress among dental students at the University of Jordan. J Dent Educ. 2011;75:1107-14.

29. Peker I, Alkurt MT, Usta MG, Turkbay T. The evaluation of perceived sources of stress and stress levels among Turkish dental students. Int Dent J. 2009;59:103-11.

30. Wilson V, Rayner C, Gordon N, Shaikh A, Crombie K, Yasin-Harnekar S. Perceived stress among dental students at the University of the Western Cape. SADJ. 2015;70:255-9.

31. Aboalshamat K, Hou X-Y, Strodl E. Psychological well-being status among medical and dental students in Makkah, Saudi Arabia: A cross-sectional study. Med Teach. 2015;37:S75-81.

32. Halboub E, Alhajj MN, AlKhairat AM, Sahaqi A-AM, Quadri MFA. Perceived Stress among Undergraduate Dental Students in Relation to Gender, Clinical Training and Academic Performance. Acta Stomatol Croat. 2018;52:37-45. http://dx.doi.org/10.15644/ asc52/1/6

33. Babar MG, Hasan SS, Ooi YJ, Ahmed SI, Wong PS, Ahmad SF, et al. Perceived sources of stress among Malaysian dental students. Int J Med Educ. 2015;6:56-61. http://dx.doi.org/10.5116/ijme.5521.3b2d

34. Naidu RS, Adams JS, Simeon D, Persad S. Sources of stress and psychological disturbance among dental students in the West Indies. J Dent Educ. 2002;66:1021-30.

35. Humphris G, Blinkhorn A, Freeman R, Gorter R, Hoad Reddick G, Murtomaa H, et al. Psychological stress in undergraduate dental students: baseline results from seven European dental schools. Eur J Dent Educ. 2002;6:22-9. http://dx.doi.org/10.1034/j.16000579.2002.060105.X

36. Murphy RJ, Gray SA, Sterling G, Reeves K, DuCette J. A comparative study of professional student stress. J Dent Educ. 2009;73:328-37.

37. Menck Sangiorgio JP, Medeiros Araujo P, Hirata Navarro C, Renan Zen I, da Costa SC, Vivan Ribeiro PH, et al. Dental Environment Stress: Findings among Lusophone Dental Students. Pesqui Bras Pediatric Dentistry Clin. 2016;16:411-24.

38. Uraz A, Tocak YS, Yozgatligil C, Cetiner S, Bal B. Psychological well-being, health, and stress sources in Turkish dental students. J Dent Educ. 2013;77:1345-55.

39. Crego A, Carrillo-Diaz M, Armfield JM, Romero M. Stress and academic performance in dental students: the role of coping strategies and examination-related self-efficacy. J Dent Educ. 2016;80:165-72.

40. Sanders A, Lushington K. Sources of stress for Australian dental students. J Dent Educ. 1999;63:688-97. 